\title{
Dom Sebastião contra Napoleão: a guerra sebástica contra as tropas francesas
}

\author{
Jacqueline Hermann*
}

\begin{abstract}
Q uando os rumores de uma possível invasão francesa começaram a circular em Portugal, no início de 1805, as pressóes dos emissários de Napoleão para que dom João, príncipe regente desde 1799, obrigaram o reino a abandonar a postura de neutralidade ${ }^{1}$ que procurara manter na política internacional desde fins do século XVIII. A guerra entre França e Inglaterra e as características da expansão napoleônica inviabilizavam qualquer possibilidade de neutralidade no conflito que atingia toda a Europa.

A Espanha se aliou aos franceses e declararou guerra à Inglaterra, em dezembro de 1804, depois da captura de fragatas hispânicas vindas da América. Em Portugal, a nobreza achava-se dividida entre o que ficou conhecido como "partido inglês" e "partido francês". No primeiro grupo incluíamse os que, mesmo adeptos de idéias liberais, tinham horror à revolução e à ofensiva antimonárquica que os franceses lideravam. Dom Rodrigo de Souza Coutinho, secretário de Estado da Marinha e do Ultramar entre 1796 e 1801, assistira à revolução em Turim, como embaixador português, e, apesar de leitor de Adam Smith, preocupava-se fundamentalmente com a manutenção da integridade do império ultramarino e da monarquia portuguesa, para a qual entendia ser necessária a aliança com a Inglaterra. Dom Rodrigo foi um dos maiores expoentes desse "partido" e antigo defensor da transferência da família real portuguesa para a América. Ainda em 1803, dom Rodrigo advogava a causa da mudança da sede da monarquia e a criação de um poderoso Império no Brasil, "donde se volte a reconquistar o que se possa ter perdido na Europa”. ${ }^{2}$ A tese de dom Rodrigo de Souza Coutinho seria acatada poucos anos depois com o auxílio da poderosa armada britânica.
\end{abstract}

* Esta pesquisa conta com o apoio do CNPq.

Topoi, Rio de Janeiro, dezembro 2002, pp. 108-133. 
Do lado dos franceses, destacava-se a liderança de Antônio de Araújo de Azevedo, que, mesmo avesso às idéias jacobinas, acreditava que a aproximação com a França seria positiva para neutralizar a já desmesurada presença inglesa nos assuntos do reino. Desde 1797, Araújo de Azevedo, estando em Paris, tentara acordar um tratado econômico e militar entre Portugal e França, momento em que os franceses avançavam vitoriosamente na Europa central. Este tratado não chegou a ser firmado, tendo sido decisiva a influência de dom Rodrigo de Souza Coutinho junto a dom João.

A maior ou menor pressão, ora do "partido inglês", ora do "partido francês", e a maior ou menor capacidade de efetivamente influenciar a política externa portuguesa, permitem-nos questionar o êxito da política de neutralidade perseguida pela monarquia e pela nobreza lusitanas. Quando, em 1792, dom João assumiu os negócios do reino, Portugal passava por graves problemas políticos internos e externos. Internamente, o afastamento de dona Maria I, causado por problemas mentais, fez do príncipe um regente tíbio, pois só em 1799 assumiria efetivamente o governo. Nesse período de sete anos, as pressões externas decorrentes da Revolução Francesa e as conseqüências da independência das colônias americanas só aumentaram, e a falta de uma direção segura do reino facilitou uma divisão da nobreza entre os dois "partidos". O verdadeiro jogo de xadrez em que se transformou a política internacional na passagem do século XVIII para o XIX, fez dos países ibéricos presas indefesas do embate continental, travado, principalmente, entre França e Inglaterra.

Sem que entremos nos detalhes de todas as idas e vindas das alianças estabelecidas em período tão incerto e grave, interessa aqui recuperar o clima de instabilidade diante do futuro imediato. Os acordos firmados entre os países podiam se alterar com os resultados de batalhas ou de novos ajustes diplomáticos. Assim, se não tiveram sucesso as pressões de Napoleão, e sobretudo de Junot - embaixador francês em Lisboa - , para que Portugal rompesse com a Inglaterra em 1805, não tiveram sucesso, isso tampouco significou uma medida de oposição explícita à França, o que Portugal procurou demonstrar com o acolhimento da esquadra que chegou à Bahia, em 1807, com Jerônimo Bonaparte, irmão do imperador. ${ }^{3}$ Em 1806, a derrota franco-espanhola em Trafalgar levou os franceses a adiarem o pla- 
no de chegar a Inglaterra e invadir Portugal e seus domínios coloniais. Nesse mesmo ano foi enviada ao reino português a "missão Rosslyn", com o intuito de restabelecer as bases da ajuda britânica e proteger Portugal de um ataque francês. Caso não fosse possível assegurar a defesa do reino, era chegada a hora de realizar o projeto de dom Rodrigo de Souza Coutinho: transferir a Corte para a América. O bloqueio continental estabelecido por Napoleão, neste mesmo ano, tornou o cenário ainda mais dramático, inclusive com risco de ataque à esquadra que traria a família real portuguesa para o Brasil. ${ }^{4}$

Mas os acenos franceses visando a um acordo foram totalmente desmentidos pelo secreto Tratado de Fotainebleau, firmado em outubro de 1807, entre França e Espanha, no qual acordavam a divisão de Portugal em três partes: a Lusitânia, ao norte, formada pelas províncias de entre Douro e Minho, incluindo o Porto, destinada à regente da Etrúria; o reino de Algarves, ao sul, constituído pelos territórios do Alentejo e do Algarve, a ser oferecido a Manuel Godoy, ministro de Carlos IV, rei de Espanha; e, finalmente, Trás os Montes, Beira e Estremadura, que ficariam sob a ocupação francesa, podendo ser devolvidos aos Bragança em troca de colônias espanholas sob domínio inglês. As colônias portuguesas seriam divididas entre a França e a Espanha e o rei de Espanha seria o imperador das "Duas Américas". 5

Mesmo não tendo jamais sido publicado, este tratado explicitava o custo da resistência portuguesa à adesão aos franceses, ao mesmo tempo em que revolvia a ferida de uma nova submissão de Portugal a Espanha. Não há dúvida de que os cenários eram agora absolutamente distintos, pois, se Felipe II comandava, em 1580, o maior império europeu, no início do XIX a Espanha era um país aliado e subordinado às tropas de Napoleão. Mas a presença, novamente, de uma futura rainha espanhola, em Portugal, aguçava ainda mais os ânimos de parte da nobreza - e não sem razão. Em 1805 Carlota Joaquina urdira um conluio palaciano visando a substituir dom João na Regência, mas o plano acabou desbaratado, o que custou o desterro temporário da infanta espanhola. ${ }^{6}$

A saída para o iminente ataque francês foi literalmente o porto. Através de uma negociação secreta com a Inglaterra, e depois de uma nova ro- 
dada de negociações fracassadas com o "partido francês", em 26 de novembro de 1807 foi decretada a transferência da família real portuguesa para o Brasil. O governo do reino passou a ser dirigido por um Conselho de Regência, que, dentre outras questóes, determinava que estariam assegurados todos os privilégios dos nacionais, comprometia-se com a conservação da paz do reino e em assistir o imperador dos franceses dando-lhes "tudo que lhes for preciso, enquanto se detiverem neste Reino, evitando qualquer insulto que se possa perpetrar, castigando-o rigorosamente quando aconteça”. ${ }^{7}$ Em 30 de novembro entraram em Lisboa as tropas de Junot com o objetivo de "proteger" os portugueses da nefasta influência inglesa, dando início a uma fase amistosa entre parte da nobreza, que ficara no reino, e o enviado de Napoleão.

Na verdade, evidenciava-se uma dicotomia no mínimo contraditória: o "partido inglês", representado pelo próprio dom Rodrigo de Souza Coutinho, seguiu com dom João para o Brasil, e o "partido francês" ficou no reino, fazendo as "honras da casa" para Junot, oferecendo-lhe inclusive o lugar de presidente do Academia de Ciências de Lisboa — além de colaborar com oficiais para as tropas do "protetor". ${ }^{8}$ A situação chegou ao seu ponto máximo quando, em dezembro de 1807, a bandeira francesa foi hasteada no Castelo de São Jorge, levando o povo a reagir contra a evidente ocupação aos gritos de "Viva Portugal, vivam as cinco chagas e morra a França”. A referência às chagas trazia de volta a memória da gloriosa batalha de Ourique, ocorrida em 1139, e transformada em "milagre de Ourique" no século XV, quando tornou-se verdadeiro mito de origem da nacionalidade portuguesa ${ }^{9}$ e símbolo primeiro da força sagrada que marcara o destino soberano de Portugal. A batalha, travada entre portugueses e mouros, fora, então, vencida pelos lusos, apesar da desvantagem numérica de homens, depois da aparição de Cristo a Afonso Henriques. Desígnio divino, a soberania lusitana estaria resguardada pela vontade sagrada, que, em pleno século XIX, voltaria a ser reclamada.

A ambição de Junot de se tornar senhor do reino ficou definitivamente comprovada com a extinção do Conselho de Regência e a destituição da dinastia de Bragança em 1o de fevereiro de 1808. Junot passou a chefiar o novo Conselho de Governo, composto por três franceses residentes em 
Portugal, e por conselheiros portugueses. Chegava ao paroxismo a divisão da nobreza portuguesa: enquanto dom Rodrigo de Souza Coutinho redigia no Brasil um Manifesto ou exposição justificativa do procedimento da Corte a respeito da França, ${ }^{10}$ ex-integrantes do Conselho de Regência, que então deviam obediência a dom João, passaram a fazer parte do governo de Junot, como foi o caso de Francisco Antônio Herman. As insígnias da Casa de Bragança foram retiradas de todos os documentos oficiais, que passaram a ser assinados "em nome de S. M. o Imperador dos Franceses, Rei de Itália, Protetor da Confederação do Reno". ${ }^{11}$ Parte importante da aristocracia aderiu à causa francesa e passou a propagandear as vantagens da aliança com Bonaparte, e mesmo a possibilidade de um príncipe da linhagem do imperador, enquanto Junot trabalhava para ser rei de Portugal!

O paradoxo da situação não poderia ser mais eloqüente: enquanto Bonaparte combatia o Antigo Regime, embora no curso das guerras tenha se auto-proclamado imperador dos franceses, um grupo de magistrados e letrados portugueses queria que o imperador lhes desse um herdeiro de sangue "nobre". Demonstrando a fratura da nobreza, os "afrancesados" aceitaram a destituição da dinastia de Bragança por um imperador, ou seu valido, cuja "nobreza" não era concedida pelo nascimento, mas pela força do talento no manejo das armas, dos acordos secretos e muitas vezes não cumpridos, na capacidade de fustigar e vencer os inimigos. Portugal tinha um regente no Brasil e outro no reino, sobretudo em Lisboa, onde os Bragança tinham desafetos e nobres avessos a qualquer mudança e que reprovavam a partida da família real. ${ }^{12}$

A resistência aos franceses começou no dia 16 de junho de 1808, dia de Corpus Christi, no Porto, seguindo-se a outra insurreição, em Lisboa, no mesmo dia, quando a procissão saiu sem o santo padroeiro - São Jorge. $\mathrm{O}$ povo, inconformado com a ausência da imagem do santo, agitou-se quando foi anunciada a chegada de uma esquadra inglesa no Tejo. O movimento restaurador evoluiu da periferia para o centro, começando pelas zonas mais desguarnecidas e próximas da fronteira espanhola para os locais onde a presença francesa era mais sentida. ${ }^{13}$ Mas, apesar da expectativa popular, só em agosto os ingleses se envolveram diretamente no combate aos franceses, e sem qualquer consulta ou acordo prévio com os portugue- 
ses. ${ }^{14}$ As forças inglesas foram, no entanto, decisivas para o recuo das tropas de Junot, que se renderam depois da derrota em Vimeiro, em 21 de agosto. A Convenção de Sintra, que selou a rendição em 30 de agosto de 1808 , contou apenas com a presença de representantes dos dois países: do lado francês, o general Kellerman; do lado inglês, o tenente-general Georges Murray. A Convenção determinou, dentre outras cláusulas, que todas as praças, fortes e fortalezas ocupadas pelos franceses passariam ao domínio inglês; que os ingleses forneceriam todos os meios de transporte para a retirada francesa; não deveria haver qualquer limitação ao envio de bens para a França; nenhum português seria penalizado por sua conduta política durante a ocupação, passando todos à proteção dos comandantes britânicos, anistiando-se, assim, todos os "afrancesados". Em março de 1809 os franceses voltaram a entrar em Portugal, sendo expulsos em maio pelas forças de Beresford. Em agosto de 1810, uma nova invasão chegou a dominar Coimbra, mas, em setembro, as forças mais uma vez lideradas por Junot foram vencidas. Estava encerrada e derrotada a expansão napoleônica em Portugal.

O sentimento de orfandade que atingira todo o reino - mesmo os afrancesados que esperavam um novo rei da "dinastia" Bonaparte — ganharia com a "Restauração" renovado ânimo. Estranha "Restauração" essa que não trazia de volta o príncipe, nem fora comandada por forças portuguesas, mas, apesar de ressabiado, o povo comemorou nas ruas a expulsão dos franceses, em fins de setembro de 1808. Os generais Wellesley e Beresford foram considerados libertadores de Portugal, mas o reino continuava acéfalo. A referência a Ourique, a falta de um rei, a ausência do regente e da família real despertaram sentimentos de tristeza e nostalgia já bastante conhecidos entre os portugueses. $\mathrm{O}$ momento revivia o tempo glorioso que dera início à dinastia bragantina, dezembro de 1640, quando dom João IV assumiu o trono português e deu fim à dominação filipina, iniciada em 1580. Durante sessenta anos Portugal estivera sem um rei português no comando, e a analogia com a ocupação francesa era inevitável, como inevitável seria também o recrudescimento do sebastianismo, crença messiânica que, não à toa, tinha surgido no rastro dos acontecimentos que antecederam a União Ibérica. 
O sebastianismo brotou e se disseminou nos mais variados cantos do reino e entre os mais diversos grupos sociais a partir de um cenário muito específico da história portuguesa que uniu o mito do Encoberto, de longuíssima duração, ao dramático momento político vivido pelo reino no final do século XVI. Para tentar compreender sua força e longevidade é preciso recuar no tempo e reencontrar as raízes de uma crença que se estruturou a partir da dor pelo desaparecimento de um sem-número de portugueses que lutaram ao lado do rei dom Sebastião, seguida da perda da soberania duramente conquistada pelos portugueses.

Nascido em 1554, pouco depois da morte precoce de seu pai, último filho vivo de dom João III, dom Sebastião foi recebido com júbilo pelo reino que via, aliviado, o nascimento de um sucessor legítimo para o trono português. $\mathrm{O}$ nascimento de um varão português afastava, uma vez mais, a possibilidade de união dos reinos de Portugal e Castela, ambicionada pelos espanhóis havia séculos. Ansiado e festejado, recebeu de seus futuros súditos o codinome de Desejado, e sobre ele recaiu a imensa responsabilidade de retomar os caminhos gloriosos do reino que fora a vanguarda na expansão da fé cristã no Norte da África e a ponta de lança dos descobrimentos ultramarinos.

Dom Sebastião foi alevantado rei de Portugal quando tinha apenas três anos de idade e cresceu em meio a disputas palacianas que se dividiram entre a forte resistência à influência espanhola na gerência da educação do menino rei, liderada pelo cardeal dom Henrique, e a constante ameaça castelhana representada pela rainha dona Catarina de Habsburgo, sua avó e tutora. Ao assumir o reinado, em 1568, o Desejado encontrou um reino politicamente instável e a nobreza dividida entre os que apoiavam o abandono das praças do Norte da África e aqueles que estimulavam a retomada do antigo e ousado sonho de fundação de um império português no coração da Berberia.

A realização dessa verdadeira "cruzada", deslocada no tempo a essa altura, daria continuidade à histórica importância do reino no seio da cristandade, marcada originalmente pelo já mencionado milagre de Ourique, resgatado como símbolo da luta da independência portuguesa quando Junot ousou hastear a bandeira francesa no Castelo de São Jorge. Além de Ouri- 
que, outro marco da confirmação da autonomia política lusitana foi a batalha de Aljubarrota, na qual os castelhanos foram derrotados em 1385, emergindo vitorioso o dom João, o Messias de Lisboa e primeiro rei da gloriosa dinastia de Avis. Dom Sebastião integrava esse panteão e, por inexperiência e excessiva confiança no tio poderoso - ninguém menos que Felipe II de Espanha - , arriscou-se na aventura africana: em 4 de agosto de 1578 desapareceu nas areias do Marrocos, com boa parte de seu exército, estimado em torno de 20 mil homens.

O desaparecimento de dom Sebastião, que não se casara e não deixara herdeiro para o reino, levou o velho cardeal dom Henrique, tio-avô do Desejado, a assumir a direção do reino. Com sua morte em 1580, e depois de uma disputa sucessória acirrada entre diversos pretendentes, Felipe II entrou em Lisboa e, nas Cortes de Tomar, jurou respeitar a autonomia do reino português, que passava a estar "unido" à coroa de Espanha. A espera pela volta do rei e dos parentes que participaram da batalha ajudou a alimentar a crença difusa na volta de um rei salvador que resgatasse Portugal dos usurpadores castelhanos. Alcácer Quibir representava uma dupla e terrível derrota para os portugueses: depois de derrotados pelos mouros, viamse submetidos aos espanhóis, exatamente os dois inimigos frente aos quais tinham conseguido firmar a independência do reino.

O período da União Ibérica, como queriam os espanhóis, ou da dominação filipina, como entendiam os padres que alimentaram o sermonário de resistência aos castelhanos, foi o tempo do surgimento da crença sebástica, para a qual foi também de fundamental importância o enraizamento da cultura judaica na Península Ibérica. O salvador Desejado e Encoberto estruturou-se a partir da espera da vinda do Messias davídico, que poderia chegar a qualquer momento, "Hoje se ouvires a Sua voz", trazendo um novo tempo de paz e harmonia. Não faltaram ao sebastianismo nem um "Profeta" nem incontáveis cáculos sobre a hora da vinda do Encoberto, divulgados em diferentes ocasiōes desde fins do século XVI. ${ }^{15} \mathrm{O}$ maior "profeta" do sebastianismo foi Gonçalo Annes Bandarra, humilde sapateiro da vila de Trancoso. Bandarra foi preso e condenado pela Inquisição portuguesa em 1541, acusado de fazer livre interpretação da Sagrada Escritura. Vivendo em meio a uma comunidade de judeus recém-conver- 
tidos ao cristianismo, era considerado por alguns um verdadeiro rabi, leitor do Talmud e da Bíblia, sobretudo do Antigo Testamento. A Bandarra foi atribuída a autoria de um conjunto de Trovas que acabariam transformadas, pouco mais de um século depois, nas "Profecias" do sebastianismo. Nestas estaria prevista a volta do Messias que os sebastianistas entenderam, décadas depois, ser dom Sebastião. As trovas de Bandarra foram tão resistentes ao tempo como o próprio sebastianismo. A primeira edição parcial foi publicada em 1602, em Paris, pelo fidalgo dom João de Castro, emigrado que fugira do reino com a chegada dos espanhóis. ${ }^{16}$ Depois da Restauração, em 1644, tem-se notícia da primeira versão completa dos escritos do pobre sapateiro, numa sucessão de ediçôes e de textos nem sempre idênticos. Para o que aqui nos interessa, vale dizer que, em 1809, surgiu em Barcelona aquela que foi considerada a edição completa dos escritos proféticos de Bandarra, seguida de novas reedições em 1810 e 1815 em Londres, onde se encontravam outros tantos emigrados portugueses. ${ }^{17}$

Transformado, para boa parte dos portugueses, em uma espécie de símbolo da resistência da autonomia e da soberania lusitana, e profundamente marcado pela nostalgia da perda da grandeza do reino que fora a vanguarda da aventura ultramarina, o sebastianismo foi retomado com força sempre que Portugal viveu crises políticas graves, como a que se repetia com a invasão e aocupação francesa e a conseqüente vinda da família real para a América. Não são raros os trabalhos que fizeram do sebastianismo uma espécie de ideologia de resistência política à dominação castelhana, por exemplo, estabelecendo uma relação direta entre o sebastianismo e a Restauração de 1640. Para isso teriam contribuído imensamente os sermões que, aproveitando os púlpitos das igrejas, faziam da retórica barroca um meio para demonstrar seu desgosto e desaprovação diante dos invasores, destacando o importante papel desempenhado pela Companhia de Jesus nessa luta surda, embora a onda de protesto sermonário não tenha se restringido a uma única ordem religiosa. Este sermonário foi instrumento político poderoso de resistência e uma verdadeira parenética foi produzida durante a dominação espanhola e depois da Restauração. ${ }^{18}$ Foi também intensa a ação do clero durante a ocupação francesa, e o próprio Junot chegou a recorrer aos homens da igreja para acalmar a população com sermões 
favoráveis à causa napoleônica. ${ }^{19}$ Segundo Ana Cristina Bartolomeu de Araujo, quando a resistência aos franceses se alastrou pelo campo, foi grande a participação do baixo clero na disseminação do fervor da "Restauração". O arcebispo de Braga, dom José da Costa Torres, outorgou-se o título de general à frente de seu batalhão; na diocese de Aveiro dom Antônio José Cordeiro mandou armar todos os eclesiásticos regulares e seculares; no Porto o bispo contou com seus prelados, com destaque para os Dominicanos; em Coimbra os eclesiásticos estiveram à frente do povo e das ordenanças, dirigidos pelo reitor do seminário episcopal, José da Costa e Silva, formando um corpo de 350 integrantes; em fins de 1808 o Tribunal do Santo Ofício promoveu a criação de um batalhão patriótico, composto de familiares residentes em Lisboa. Os excessos patrióticos dos clérigos, no entanto, não foram unanimidade entre os religiosos, e chegaram a ser condenados pelo arcebispo dom Frei Manuel do Cenáculo. ${ }^{20}$

$\mathrm{O}$ envolvimento do clero deu à resistência um evidente tom religioso, fortemente instigado pelo caráter laico da revolução. A demonização dos franceses, de Napoleão e sobretudo da revolução teve propagandistas não só entre os religiosos, mas homens da estirpe de Edmund Burke, para quem a revolução era uma "monstruosa tragicomédia", e do abbé Barruel que vociferava que "depois de terem jurado esmagar Jesus Cristo, esses mesmos homens chamados Filósofos, formularam ainda o voto de esmagar os Reis". Em Portugal o impacto não foi diferente, e mesmo entre os "afrancesados" havia os que continuavam a esperar a coroação de um rei, mesmo que francês. Lúcia Maria Bastos Pereira das Neves analisa com argúcia e profundidade as representações napoleônicas em Portugal no período de 1808 a 1810. Dedica parte de seu trabalho à construção das imagens de Napoleão, combinando mito e história para recuperar a elaboração da "lenda negra" e da "lenda rosa" tecida em torno do Imperador dos franceses. Na França imperial, entre 1800 e 1814, prevaleceu a combinação de herói e semideus; na Europa, invadida pelas tropas francesas construía-se a "lenda negra", divulgada através de mais de 500 brochuras inglesas, russas, alemãs, espanholas e portuguesas. ${ }^{21}$

A produção e circulação de panfletos e escritos de teor político tiveram, no início do século XIX, um papel fundamental na construção e dis- 
seminação dessas imagens e, em Portugal, a partir de 1808, um verdadeiro surto editorial tomou conta do reino. Essa produção contou também com escritos de inúmeros integrantes do clero que consideravam a resistência antifrancesa como uma "guerra da Religião e do Estado". Frei Joaquim Soares considerava a revolução uma aberração que atingia os princípios "da razão e da ordem (e) queria destruir os dois poderes régio e sacerdotal, bases fundamentais da sociedade". Uma verdadeira "cruzada contra-revolucionária” tomava conta de Portugal e, ao contrário dos panfletos e publicações que, na França, circulavam pelas tabernas disseminando as idéias revolucionárias, ${ }^{22}$ entre os portugueses prevalecia o espírito monárquico e conservador.

O mesmo tom de exaltação e revanche marcara vários textos surgidos nos momentos das duas "Restauraçôes". Textos como o da Relação histórica dos principaes successos acontecidos no Reino de Portual, desde a infausta entrada dos francezes neste reino até a Restauração do seu legitimo governo, de 1808, ou dos Successos de Portugal ou prodigiosa Restauração da Lusitania Feliz. Por hum Portuguez que ama a Religiāo, a Pátria e o seu Augusto soberano, publicado em 1809, para não citar os inúmeros sermões proferidos por ocasião da expulsão dos franceses, recriaram o mesmo clima de 1640. Restauração de Portugal prodigiosa, de autoria do padre João de Vasconcelos, foi publicado sob o pseudônimo de Gregório de Almeida, em 1643, e Lusitania Liberata, de Antônio de Sousa de Macedo, de 1645, poderiam ser títulos de escritos oitocentistas. ${ }^{23}$

A nostalgia que tomou conta do reino depois da União Ibérica reapareceria com toda força durante a ocupação napoleônica, trazendo de volta à cena política o outrora Desejado e Encoberto dom Sebastião. A ausência de dom João e de toda a família real realimentou o sentimento de abandono e tristeza que ajudara a sedimentar o nascimento da crença sebástica na passagem do século XVI para o XVII. O início dos oitocentos assistiu a uma nova onda do ímpeto sebastianista, agora confrontado, dentro do reino, pelas correntes que se consideravam racionalistas. Vale destacar aqui que, ao contrário do que muitos críticos de dom Sebastião e dos sebastianistas apontaram, vemos ressurgir nesse momento, além da revolta popular, um sebastianismo letrado, profuso e articulado a um discurso que procurou 
misturar fé e racionalidade para construir seus argumentos. Não se trata, como veremos, de "pura crendice de ignorantes", mas de um conjunto expressivo de escritos que, na onda do furor editorial do período, nos permite identificar a sobrevivência do sebastianismo, suas readaptações ao tempo e às diferentes conjunturas, e confirmar sua plasticidade e longevidade.

A documentação a seguir analisada integra um conjunto de publicações difícil de quantificar com precisão. Dispersos nos arquivos portugueses, muitos desses documentos provavelmente não foram preservados, inúmeros são anônimos, outros tantos jocosos, não sendo fácil identificar o perfil e as intençôes de todos os que se engajaram na defesa ou ataque das hostes de dom Sebastião. Assim sendo, os escritos aqui reunidos, embora indiquem com segurança a importância assumida por esse debate em meio a mais um doloroso momento político português, longe estão de esgotar a campanha pró e anti-sebastianista que Portugal conheceu no início dos oitocentos.

O embate entre defensores e opositores da validade dos argumentos sebastianistas deslocou a batalha para o território das letras e deu corpo àquela que ficou conhecida como "guerra sebástica". Expressão surgida provavelmente em um escrito anônimo que circulava em Lisboa em 1810, Carta de um provinciano a um amigo seu sobre a Guerra Sebástica, tudo indica que pretendia responder à raivosa e ofensiva brochura publicada pelo padre José Agostinho de Macedo (1761-1831), Os sebastianistas. Reflexóes críticas sobre esta ridícula seita, também de $1810 .{ }^{24}$ Para o autor da Carta "esta nova guerra de penna póde chamar-se Guerra Sebástica; e oxalá fora a única que tivessemos a temer". Entendia ser esta "guerra" imprópria para a época, devendo os homens que se ocupavam de "ninharias (...) applicar o tempo que consomem pueril e ridiculamente, ou em esclarecer seus Concidadãos, ou em ridicularizar o Gran-Bigamo, Cidevant Napoleão.”

Mas antes mesmo da publicação de Macedo, tendo talvez motivado a pena irada do padre, circulou em Lisboa o texto Exame e juízo crítico sobre o papel intitulado Anti-sebastianismo, annunciado na Gazeta de Lisboa de 28 de setembro de $1809 .{ }^{25}$ Afirmava o autor anônimo que

se algum homem estava no caso de viver séculos, seria El Rei Dom Sebastião (...), em que concorria tudo quanto pode julgar-se necessário para go- 
zar uma vida longa. Moço robusto e vigoroso, inimigo de melindres e efeminações, muito dado a exercícios, sóbrio e livre de vícios torpes (...) superior às paixões e desgraças que envenenam a massa vital (...), ora um homem com todas estas circunstâncias promete uma longa duração.

Além de retomar os valorosos atributos de um verdadeiro rei guerreiro, este opúsculo não deixava de responder energicamente aos que tomavam os sebastianistas como estúpidos e irracionais:

pois não vejo que a esperança (no sebastiansimo) mereça ser tratada de ridícula, absurda ou revoltante, nem que esta seita mereça ser confundida com as dos que crêem em estupidezas (...), ao contrário, o sebastianismo no seio do século talvez o mais ilustrado e judicioso de todos, homens de muito juízo, de muito saber, e de muita crítica, tem sido e ainda nos nossos dias são seus acérrimos sequazes.

Estimulado por defesas como essa, José Agostinho de Macedo publicou seu explosivo opúsculo. Personagem controvertido, suas biografias nos mostram uma personalidade atravessada pelas angústias de um tempo dividido entre a tradição e a razão. Polemista e colérico, granjeou muitos inimigos, o que certamente comprometeu as informaçóes que hoje conseguimos recuperar sobre ele. Frade da Ordem de Santo Agostinho em 1778, foi expulso da Ordem e enviado para o convento da Graça de Évora em 1782, depois de reiteradas acusaçôes de roubo de livros e de viver publicamente em concubinato. Sua proximidade com a rainha dona Maria I o livrou do cárcere, mas sua vida tumultuada e seus escritos sempre acalorados e insultuosos sobre uma imensa gama de assuntos mereceram de Oliveira Martins a seguinte avaliação: "A sua veia (hoje diz-se verve), a sua facúndia, eram inesgotáveis. Sabia a linguagem das colarejas e rameiras, porque as freqüentava; e o calão dos cárceres e das enxovias, porque passou por lá”. Carlos Olavo, um de seus biógrafos, o considerava

um vesânico. A fúria vinha-lhe da alma como a água da nascente. Antes dos seus furores políticos já existiam os seus furores literários. José Agostinho era, diante do adversário que lhe fazia frente, uma fera; sentiam-se mesmo, na sua polêmica, os guinchos da fera perseguida, o desejo de morder, de atassalhar, de trucidar (...). ${ }^{26}$ 
Importa pouco aqui argüir sobre a vida de José Agostinho de Macedo. $\mathrm{O}$ que se pode constatar é que, por mais escandaloso que fosse, Macedo produziu uma vasta obra, para muitos de qualidade discutível, e chegou a merecer estudos sobre suas motivações iradas e o número exagerado de textos publicados, cerca de 225 títulos! Parece não haver dúvida de que Macedo foi um dos detonadores da "guerra sebástica" com a publicação de sua bombástica crítica aos sebastianistas, acusados de serem maus cristãos, maus vassalos, maus cidadãos e os maiores de todos os tolos.

Macedo justifica a necessidade de seu ataque indignado:

Por mais que o tempo, os sucessos e a boa razão desmintão, a seita se multiplica como huma teima tal, que obrigou a lançar por escrito as seguintes reflexões (...). Os livros que os Sebastianistas citão, como Profecias do Bandarra, Restauração de Portugal prodigiosa, Vida do Çapateiro Santo Simão Gomes, se achão condemnados e proscriptos pela Real Meza Censoria. O rectíssimo Tribunal do Santo Offício comndenou muitos dos fautores e assoalhadores das suppostas Profecias (...). Por estes motivos, e pela obrigação de bom Patriota, o que tenho feito conhecer por escritos, e de viva voz em sagrados discursos ao Povo, e o attestarei com a vida, sendo preciso para conservação e defesa da nossa Patria, da nossa Religião, e do nosso Monarca, julguei conveniente desabusar esta Seita de crédulos, que na verdade são prejudiciais á segurança, e defesa do Reino, em quanto fiados nas ridiculas Profecias permanecem indolentes para tudo (...). ${ }^{27}$

O texto está dividido em quatro partes, nas quais o autor procura demonstrar suas afirmações. Na primeira proposição, Hum sebastianista he hum máo Christão, Macedo considera o sebastianismo uma heresia política, e reconta a história da batalha de Alcácer Quibir, poupando a imagem de dom Sebastião ("coração magnânimo e digno de um Rei Portuguez") mas afirmando a morte do monarca, pois

Se he mentirosa a morte d'elRei Dom Sebastião nos campos de Alcacerquibir, não há história no mundo que verdade falle, nem documentos por authenticos que sejão, a que se deva dar crédito (...); porque quando se desvaneceo a esperança de sua natural conservação passado hum século, em que podia viver sem milagre, continuou a esperança da vinda afiançada em sobrenatural e milagrosa conservação; porque, bem estirados como o coiro, para tudo davão os destempêros attribuidos a Bandarras, que commentados 
depois com outros machiavelicos projectos derão com Antonio Vieira no Santo Officio de Coimbra. / Tal foi a origem, e taes os primeiros progressos da delirante Seita Sebastica. ${ }^{28}$

Defensor do Santo Ofício, Macedo faz aqui seu primeiro ataque direto ao famoso jesuíta Antônio Vieira, conhecido crítico da Inquisição e da perseguição aos cristãos novos. Mas o argumento principal de Macedo para comprovar sua proposição baseava-se na premissa de que

Hum dos maiores peccados contra a Religião, he sem dúvida tentar a Deos n.Senhor querendo obrigallo a fazer milagres.(...) Os Sebastianistas sem Deos os mandar, (...) querem que Deos suspenda as leis da Natureza, e que faça e seja obrigado a fazer hum milagre, sem motivo, sem fim, e sem necessidade, conservando vivo, são, e escorreito a Dom Sebastiāo para continuar a ser Rei de Portugal. (...) Mas, continuão os sebastianistas, se não temos isto expresso nas Escrituras, nós o temos annuciado e escarrado nos versos de Bandarra, e nas trovas do Pretinho do Japão. Eis-aqui huma verdadeira blasfêmia. Hum Sebastianista he hum sacrílego, um tentador de deos, e hum blasfemo. ${ }^{29}$

Macedo irrita-se com a demora da volta do Encoberto: "Eu perguntára a estes mentecaptos em que occasião devêra ter apparecido o seu esperado Sebastião?” Indaga-se por que não aparecera quando Felipe II se apossou do reino, ou ainda:

não era boa occasião de apparecer o Encoberto no anno de 1640? (...). Mas não veio, deixou subir ao Throno elRei Dom João IV, seu filho, seu neto, seu bisneto, sua terceira neta a Rainha N.Senhora e não há notícia delle. E então quando há de vir? Que bella occasião se perdeo no $1^{\circ}$ de fevereiro de 1808, quando os cobardes bandoleiros introduzidos em Portugal, dêrão por acabada a Dynastia de Bragança, e fizêrão os deaforos de que fomos testemunhas, começando sem rebuço a roubar tudo, a vilipendiar esta Nação. ${ }^{30}$

Crítico feroz dos jesuítas e sobretudo de Vieira, responsabiliza-os pelo engano dos sebastianistas, pois se as promessas não se cumpriram "São pois os vossos chamados Profetas huns mentirosos solemnes, que vos enchem de confusão". E completa:

Ora confudi-vos e vedes como já vossos trovistas são môlho de pasteleiro, como já vos disse, que servem para tudo, ou são hum pão de dois bicos, 
com que os Jesuítas jogárão conforme o pedião as suas máximas para vos ludibriarem. ${ }^{31}$ "

Aqui Macedo faz alusão ao que ficou conhecido como "transfiguração barroca do Encoberto", ou seja, a mudança de identidade que o Desejado viveu ao longo da história portuguesa, referindo-se especificamente a Antônio Vieira, para quem o Encoberto das Trovas do Bandarra seria dom João IV ressucitado. ${ }^{32}$ Macedo afirma que a troca do rei deveu-se à "velhacaria” de Vieira e dos jesuítas que se aproximaram do primeiro rei da dinastia de Bragança para "introduzir-se na boa graça daquelle grande Monarca. Era preciso para o lisongear, mostrar que elle era o rei promettido, o rei Encoberto... ${ }^{33}$

Para José Agostinho de Macedo a mudança na interpretação das trovas proféticas do Bandarra era a confirmação da falta de religião dos sebastianistas, do que se depreendia sua segunda proposição: Hum sebastianista he um máo Vassalo.

Esperar pois elRei Dom Sebastião morto e sepultado há 200 pra 300 annos, e berrar e clamar que elle está vivo e encoberto em huma Ilha mais quimérica, que a do Governador Sancho Pansa, he uma manifesta rebelliào, e um clamor público de que existe intrusa no Throno a Dynastia de Bragança. ${ }^{34}$

Voltando a dialogar com as trovas que insistia em desqualificar, Macedo concentrou-se nesta segunda parte na previsão de que o Encoberto integraria a 16 ${ }^{a}$ geração de reis portugueses, interpretação particular do padre para a crença de que o Encoberto seria o 16ํㅜ rei lusitano. Depois de contas e listas dos reis portugueses, conclui que a conta dos sebastianistas estava errada, pois estes deveriam "esperar Dom Henrique, e não Dom Sebastião, e por isto se devem chamar Henriquistas, e não Sebastianistas". ${ }^{35}$ Aumentando o tom dos insultos, vocifera:

Vinde cá Bestas muares, vós esperais elRei Dom Sebastião porque o diz Bandarra, digno profeta vosso, e elle abertamente canta: o Rei novo he levantado. Se he Dom Sebastião como pode ser novo (...). Velho e relho seria elle. Só Dom João IV, he o rei novo (...). Diz mais o Profeta Bizegre: Já assoma a sua bandeira/Contra a Grifa parideira. Os Sebastianistas de 1808, e entre elles hum bem respeitável pelo carácter, e pelo Gráo de Doutor, me dizião, que chegando Dom Sebastião (a que elle muito enternecido chama- 
va o nosso Velho) levantaria logo a bandeira contra Bonaparte, cuja insígnia he a Águia, que em portuguez antigo se chamava Grifa. ${ }^{36}$

E termina a proposição afirmando:

Sendo pois pelo depoimento de seus melhores Profetas, os Sebastianistas huns máos Vassallos, em quanto vivendo debaixo da única, legítima e verdadeira autoridade, que he a da Casa Reinante, esperão, querem promettem e assoalhão outra que já não existe, são igualmente huns máos e péssimos Cidadãos. ${ }^{37}$

A dedução óbvia das duas outras proposiçôes nos permitiria interromper aqui a já longa citação do texto de José Agostinho de Macedo. Mas é preciso avançar ainda um pouco mais, pois é na $3^{\underline{a}}$ proposição que Macedo compara os sebastianistas aos "pedreiros Livres", objeto de de seu ódio desmedido. Afirma o autor:

Contemplando eu e meditando attentíssimamente sobre as desgraças da Europa, sobre as de Portugal, vejo que ellas nascerão de huma Seita detestável e perniciosíssima, que depois de se mostrar má, também se mostra pela mais tola e treloucada que existe. Esta vil canalha, a que chamamos Pedreiros livres, começou a assoalhar no Povo quiméricas e irrealizáveis ideas de liberdade e igualdade, a prometter lhe hum estado de coisas, que produziria no Mundo o Século dourado, e desta maneira illudido o dispoz para a fatal revolução, que foi o maior de todos os males que tem vindo á Terra. ${ }^{38}$

Embora Macedo faça questão de apontar diferenças essenciais entre os dois grupos, afirmando que entre os sebastianistas há homens de verdade, enquanto entre os maçons há maus cidadãos por "voluntária malícia”, um defensor de dom Sebastião é mau cidadão "por pura ignorância”, embora sejam estes igualmente "loucos varridos, doudos rematados, e tolos selemníssimos" e cúmplices involuntário dos pedreiros livres "sem o quererem, ou sem se lembrarem que o são, huns muitos máos e perniciosos Cidadãos". 39

Em que pesem todos os exageros característicos da verve colérica do padre, o texto Os sebastianistas ilustra bem a capacidade que a expectativa sebastianista tinha de catalisar as discussões em momentos críticos como o que atravessava Portugal no início do XIX. O virulento ataque de Macedo produziu um conjunto não menos indignado de respostas, boa parte delas 
anônimas, em defesa dos sebastianistas, embora nenhum dos autores se declare adepto da crença sebástica.

Ainda ao longo de 1810, inúmeras publicações ganharam as ruas. Refutação Analytica do Folheto que escreveo o Reverendo Padre José Agostinho de Macedo, e intitulou os Sebastianistas procurou responder ponto a ponto as acusações de Macedo. Sem indicação clara de autor, embora assinada "Pelos redactores do Correio da Pininsula", João Bernardo da Rocha Loureiro e Nuno Alvarez Pereira Pato Moniz ${ }^{40}$, começa declarando, na primeira pessoa: "Escrevo contra o Reverendo Padre José Agostinho de Macedo, e Prégador conhecido nesta Corte (...) porque á nossa refutação assistem os fundamentos de toda boa razão...”. Ainda no Prólogo, desqualifica Macedo como tradutor e sobre seus versos afirma que

Na parte métrica o seu grande merecimento consiste no cunho material dos versos, que ordinariamente lhe sahem sonoros e mui bem fundidos; mas que vale isto se a falta de sentimento, que em todos se nota, os faz insípidos, e as digressões sem arte, os lugares communs, e repetições provocão o tédio da leitura? (...). Devemos todavia confessar que elle tem não pequena cópia de idéias, principalmente bibliográficas, e de acontecimentos de história, as quaes muitas vezes servem de mais enfado, e estorvo ao juízo, do que de carga e pezo á memória. ${ }^{41}$

O autor afirma: "Eu não sou sebastianista nem Pedreiro Livre, porém custa-me ver tratados com injúria de regatão" homens de boa fé, e entre os quais há alguns, como o próprio Macedo admite, "Religiosos, pios e tementes a Deus". ${ }^{42}$ Sobre a acusação de maus cristãos, declara o documento que o sebastianismo, como simples crença, não pode ser considerado erro prático de cristianismo e que mesmo não tendo Bandarra por profeta, acredita que "em razão de seu officio nenhuma impossibilidade tinha para o ser". ${ }^{43}$ Afirma que Deus tem concedido aos seus servos o dom de predizer o futuro, e iguala o acusador aos acusados, ao chamá-lo de blasfemo, ímpio, "hum attentador contra Deos", pois toma a Madre Maria de São José como santa e profeta. ${ }^{44} \mathrm{O}$ texto prossegue na contestação das acusações de Macedo, procurando seguir a "lógica" de cada silogismo do autor e afirma:

porque, se os Sebastianistas querem Dom Sebastião para maior glória do reino, não são máos Christãos, porque desejão a prosperidade de hum Rei- 
no onde a Religião Christã he dominante (...); também não são máos Vassallos, porque desejão um Reino legítimo, e a quem direitamente pertencia a Corôa; e porque elles esperando Dom Sebastião, inquietão a tranquila, justa, e legítima posse dos nossos actuáes, e amados Monarchas, pelo contrário desejão que estes a conservem psoperamente; não são máos Cidadãos porque desejão a felicidade de seu Paiz; e quem deseja a sua felicidade, e a dos seus não he tolo (...). ${ }^{45}$

Em tom bem mais anemo, mas mantendo a discussão no terreno estreito das relações entre sagrado e profano, ou ainda, da legitimidade da continuação da dinastia de Avis ou da justeza da sucessão brigantina, a Refutação Analytica foi seguida por outras respostas, como a de Joaquim Agostinho de Freitas. Afirma que "Sem ser sebastianista, me proponho a demonstrar a falsidade" dos argumentos de Macedo, entendendo que

Sepultada há longos annos esta Crença no profundo somno do esquecimento, acordárão seus Sectarios no anno de 1808, e começarão de novo a revolver antigos manuscritos, e codices, oraculos da Crença, sem desta acção resultasse effectivamente prejuizo algum á Sociedade, ou Religião (...)

Para Agostinho de Freitas, os sebastianistas jamais renegaram os direitos do príncipe regente depois da "ditosa Restauração", mas concorreram com seu patriotismo: "Elles fazem huma parte da Nação, a Nação corre toda ás armas, toda coopera para a mutua segurança, e para a conservação dos Direitos de S.A.R., logo os Sebastianistas também concorrem, também cooperão". ${ }^{46} \mathrm{O}$ autor acusa Macedo de espia dos franceses: "Não me consta, que algum Sebastianista servisse com adhesão no intruso Governo Francez; fosse hum espia, e denunciante dos seus Compatriotas, e finalmente hum satélite do mencionado pérfido Governo" ${ }^{47}$

Alguns dos biógrafos de José Agostinho chegaram a levantar essa possibilidade, factível em face da "plasticidade" política do padre, que apoiaria os miguelistas em 1828, e tendo em vista a falta de unidade política da nobreza e do clero durante a ocupação das tropas francesas.

Outro opúsculo publicado para responder a Macedo foi o de Manuel Joaquim Pereira, que mais uma vez negou ser sebastianista, chegando mesmo a escarnecer da ultrapassada crença, explicando o ressurgimento sebástico pela esperança "do libertador futuro, que devia chamar á Nação, 
e á liberdade, castigar Bonaparte, e vingar a Europa de vinte annos de crimes, e immoralidades." 48

As discussões em torno da crença sebástica ensejaram também escritos jocosos como a Carta de hum guarda-roupa d'elRei Dom Sebastião a hum seu amigo nesta Corte, no qual seu autor anônimo faz "breves reflexões" sobre o escrito de Macedo. O súdito de dom Sebastião escreve da Ilha Encoberta, em 4 de julho de 1810 e diz ao amigo que lamentava a falta de notícias, suplicando aos céus para "pôr termo a esse degredo", quando viu descer "como de entre as nuvens, o Correio Aerônauta, que costuma conduzir a esta Ilha a correspondência desse longíquo hemisfério". Além de notícias do reino, recebeu também o "novo impresso, dado á luz nessa Corte para destruir nosso Partido, desterrar prejuízos, e desabusar o Mundo”. Sobre a reação del Rei afirma: "Sua Magestade o Senhor Rei Dom Sebastião, nosso Amo, tem dado ordem positiva para que nenhum vassallo seu nesta Ilha responda seriamente a semelhantes bagatélas". Mas afirma indignado:

Contudo, vendo insultar tão grosseiramente os nossos Affeiçoados, confesso que os meus bons desejos (se ahi estivera) ainda se estenderião a mais. Reprehender leaes vassallos só porque se conservão fiéis aos seu Soberano; depois que sei ler, só em dois lugares o tenho visto: nos modestos boletins da nova França, e no attencioso Folheto que me mandaste. Escarnecer de nossos Profetas, e duvidar das suas infallíveis predicções, só por serem pobres, humildes e de ofícios mecanicos (como se para o ser fosse necessário apresentar quatro avós nobres), he positivo desafforo (...)

E sobre a possível sobrevivência do Desejado declara atônito:

Duvidar da existencia de nosso Amo, he um crime de lésa-razão; porque aqui estou eu, que também morri na batalha, e só por ser de sua comitiva, agora te estou escrevendo./Dizer que Deos não tinha necessidade de conservar hum indivíduo por tantos annos, he redonda asneira. Sabe, por ventura, o Author as necessidades que Deos tem? Não lhe perguntarás (...) que necessidade tinha Deos de levar açoites, podendo resgatar o Mundo com mais commodidade?/Finalmente, negar nosso regresso, he huma horrível blasfemia, cujo proporcionado castigo Sua Magestade determinará á sua chegada. E demais, a não ser para recobrar o que era nosso, então para que ressuscitamos nós? Se fosse para de novo punir a imprudencia do Rei no 
temerário projecto de subjugar Africa, tê-lo-hia conservado naquellas arêas ardentes, e não em huma Ilha tão rica, tão parazível, e deliciosa (...). ${ }^{49}$

José Agostinho de Macedo, inconformado com as respostas que recebeu, e mesmo com o tom de pilhéria de diversos escritos, publicaria, ainda em 1810 , a segunda parte de Os sebastianistas, ${ }^{50}$ dando continuidade à "guerra”...

Muitos outros escritos alimentaram os debates em torno da veracidade, da seriedade ou da ingenuidade dos sebastianistas que trouxeram o rei menino de novo ao proscênio, ${ }^{51}$ apontando a impressionante permanência do tema sebástico, mais de dois séculos depois da derrota de Alcácer Quibir. Se não é fácil explicar sua permanência, tampouco é possível tratálo apenas com escárnio e zombaria. Mais que revelar a fidelidade ou a ojeriza a dom Sebastião, estes textos confirmam a sobrevivência de ingredientes que formaram e deram corpo à crença sebástica na virada do século XVI para o XVII, adaptados à conjutura imposta pelas tropas de Napoleão. Mesmo quando os sebastianistas foram ridicularizados, as narrativas demonstraram o conhecimento de detalhes do arsenal de elementos que delinearam o sebastianismo surgido nas nuvens que embaçaram os olhos e as esperanças dos contemporâneos do rei desaparecido. $\mathrm{O}$ contexto das invasões francesas e o impacto que estas causaram em Portugal, com a disseminação da maçonaria, das idéias liberais, da insegurança causada pela mudança da família real para o Brasil, e o conseqüente questionamento do pacto que estruturava a relação súdito/soberano, são apenas algumas das pistas capazes de ampliar nossa compreesão sobre a "volta" de dom Sebastião a Portugal durante o gravíssimo embate contra as tropas napoleônicas.

Os argumentos substituíram um possível hipotético crime de "lesamajestade" — a negação da legitimidade do píncipe regente dom João por um de "lesa-razão", argumento no mínimo estranho para discutir matéria de fé. Para Macedo e para os defensores do sebastianismo, tradição e razão aparecem misturadas, transformando o sebastianismo em uma ambígua "heresia política", novo campo sagrado capaz de, para alguns, fazer frente ao anticristo do momento: Napoleão Bonaparte. $\mathrm{O}$ medo disseminado pela "besta [que] saiu do mar, que rodeia uma pequena Ilha do Tirreno, 
chamda Córsega e tinha sete Cabeças e dez Cornos, e sobre os Cornos, dez Coroas" 52 foi uma das inúmeras imagens que circularam através dos panfletos que disseminavam o pânico com a iminência de uma França Imperial. Para os que haviam sonhado com a fundação do Quinto Império do Mundo em Portugal governado por um rei português, este deveria ser o momento da revanche.

\section{Notas}

${ }^{1}$ Ver Novais, F. A. "Política de neutralidade". In Portugale Brasil na crise do Antigo Sistema Colonial (1777-1808). 2. ed. São Paulo: Hucitec, 1981, pp. 17-56.

${ }^{2}$ Apud Neves, Lúcia Maria Bastos Pereira das. As representações napoleônicas em Portugal: imaginário e política (c.1808 - 1810). Rio de Janeiro. Tese apresentada para concurso de Professor Titular no Instituto de Filosofia e Ciências Humanas da UERJ, 2002, pp. 55.

${ }^{3}$ Cf idem, p. 51 .

${ }^{4}$ Para os impasses vividos em Portugal nesse momento ver, além do trabalho de L. M. B. Pereira das Neves, Araújo, Ana Cristina Bartolomeu de. As invasóes francesas e a afirmação das idéias liberais. In Torgal, Luis Reis, Roque, João Lourenço (Coords.). O liberalismo (1807-1890). Lisboa: Estampa, 1993 (História de Portugal, 5) e Lima, Oliveira. D. João VI no Brasil. 3. ed. Rio de Janeiro: Topbooks, pp. 21-41.

${ }^{5}$ Sobre o Tratado de Fontainebleau ver Alexandre, Valentim. Os sentidos do império: questão nacional e questão colonial na crise do Antigo Regime português. Porto: Afrontamento. p. 163; Lima, Oliveira. Op. cit., p. 37.

${ }^{6}$ Ver o verbete Carlota Joaquina. In Vainfas, Ronaldo (Dir.). Dicionário do Brasil Colonial (1500-1808). Rio de Janeiro: Objetiva, 2000, pp. 102-3.

${ }^{7}$ Cf. Neves, J. Acussio das. História geral da invasão dos franceses em Portugal e da restauração deste reino. Porto: Ediçôes Afrontamento, s/d. Tomo I, p. 220.

${ }^{8}$ Cf. Neves, L. M. B.Pereira das. Op. cit., p. 61-62.

${ }^{9}$ Para uma análise da construção da narrativa mítica em torno do milagre de Ourique ver Buescu, Ana Isabel. Um mito das origens da nacionalidade: o milagre de Ourique. In Bethencourt, Francisco, Ramada Curto, Diogo (Orgs.). Memória da Nação. Lisboa: Sá da Costa, 1991, pp. 49-69.

${ }^{10}$ Idem, p. 60.

${ }^{11}$ Cf. Edital de 1ํ de fevereiro de 1808. [Lisboa]: Impressão Régia, [1808].

${ }^{12}$ L. M. B. Pereira das Neves chama a atenção para essa parte da nobreza que se ressentia com a perda de espaço político junto à Regência e via nesse novo momento a oportunidade de recuperar "o seu antigo papel de conselheira nata do monarca". Neves, L. M. B. Pereira das. Op.cit., p. 141. É possível também conjecturar sobre a tentativa de "revanche" de 
parte da nobreza que havia sido perseguida desde os tempos de Pombal e que vira o regente e a rainha abandonarem o reino em momento tão difícil. $\mathrm{O}$ paradoxo dos afrancesados foi querer uma "revolução" para restaurar antigos privilégios, esperando contar, para isso, com o apoio dos franceses.

${ }^{13}$ Cf. Araújo, Ana Cristina Bartolomeu de. Op. cit., pp. 33-34.

${ }^{14}$ Cf. Neves, L. M. B. Pereira das. Op. cit., p. 69; Alexandre, Valentim. Op. cit., pp. 182183; Araújo, Ana Cristina Bartolomeu de. Op. cit., pp. 37-38.

${ }^{15}$ Para uma análise do momento constitutivo do sebastianismo português ver Hermann, Jacqueline. No Reino do Desejado: a construção do sebastianismo em Portugal, séculos XVIXVII. São Paulo: Companhia das Letras, 1998.

${ }^{16}$ Dom João de Castro apoiou dom Antônio, primo bastardo de dom Sebastião, mas preterido pelo cardeal dom Henrique por ser filho de cristão nova com um irmão do rei, dom Luís.

${ }^{17}$ As edições de 1810 e 1815 foram publicadas com os seguintes títulos, respectivamente: Bandarra descoberto nas suas Trovas, contendo uma Coleçam de Profecias notáveis, respeito a felicidade de Portugal, e Cahida dos maiores Impérios do Mundo; Trovas inéditas de bandarra; natural da Vila Francoza. Esta edição pretendia incluir o 4ำ 5 e $6^{\circ}$ corpos das trovas e apresenta um estilo bem mais rude e simplório que aquela considerada "original". Em 1823, 1866 e 1911 suegem novas ediçōes. Cf. Hermann, Jacqueline. Op. cit., pp. 54-55 e 314. Em Londres publicava-se ainda o Correio Braziliense, de Hipólito da Costa, entre 1808 a 1822, no qual Napoleão era ferozmente atacado. Cf. Neves, L M. B. Pereira das. Op. cit., p. 189.

${ }^{18}$ Sobre a relação entre sebastianismo e Restauração ver Hermann, Jacqueline. O sebastianismo e a Restauração Portuguesa. Voz Lusíada. Lisboa, Academia Lusíada de Ciências, Letras e Artes, n. 11, pp.3-16, 1999. Sobre a parenética produzida no período ver Marques, João Francisco. A parenética portuguesa e a dominação Filipina. Porto: Instituto Nacional de Investigação Científica; Centro de História da Universidade do Porto, 1986; A parenética portuguesa e a Restauração (1640-1668). A revolta e a mentalidade. Lisboa: Imprensa Nacional; Casa da Moeda, 1989, 2 vols.

${ }^{19}$ Neves, L. M. B.Pereira das. Op. cit., p. 63.

${ }^{20}$ Araújo, Ana Cristina Bartolomeu de. Op. cit., p. 36.

${ }^{21}$ Neves, L. M. B. Pereira das.Op. cit. Capítulo 1, "Napoleão: o homem e a história”, pp. 10-40 e capítulo 3, "Mitos e representações em torno de Napoleão Bonaparte", pp. 84136. Ana Cristina Bartolomeu de Araújo chega a falar em 2.000 panfletos, folhas volantes e caricaturas circulando na Península Ibérica nesse período. Cf. Araújo, Ana Cristina Bartolomeu de. Op. cit., p. 42.

${ }^{22}$ Ver a respeito Darnton, Robert. Boemia literária e Revolução: o submundo das letras no Antigo Regime. São Paulo: Companhia das Letras, 1987.

${ }^{23}$ Para os títulos do século XIX ver Neves, L. M. B. Pereira das. Op. cit. p. 71, nota 64. Para os textos do século XVII ver Azevedo, João Lúcio. A evolução do sebastianismo (1918). 
3. ed. Lisboa: Editorial Presença, 1984, p. 59 e Marques, João Francisco. A parenética portuguesa e a Restauração (1640-1668). Vol. 2, p. 425, respectivamente.

${ }^{24}$ Carta de um provinciano a um amigo seu sobre a Guerra Sebástica. Lisboa: Impressão Régia, 1810, p. 2; Macedo, José Agostinho de. Os sebastianistas. Reflexóes críticas sobre esta ridícula seita. Lisboa: Officina de Antonio Rodrigues Galhardo, Impressor do Conselho de Guerra, 1810. 114 p. Ver também Boisvert, Georges. La guerra sebástica à Lisbonne en 1810. Les dessous de la polémique. Lisboa: Fundação Calouste Gulbenkian, 1983, pp. 671685. Separata do Arquivo do Centro Cultural Português.

${ }^{25}$ Exame e juizo crítico sobre o papel intitulado Anti-sebastianismo, annunciado na Gazeta de Lisboa de 28 de setembro do presente anno. Lisboa: na Impressão Régia, 1809, p. 5.

${ }^{26}$ Dentre as biografias mais conhecidas do padre José Agostinho de Macedo destacam-se: Braga, Teófilo (Coord.). Memórias para a vida intima de José Agostinho de Macedo. 18991900, 3 vols.; Melo, Joaquim Lopes Carreira de. Biografia do P. José Agostinho de Macedo e a sua época, seguida de um catálogo alfabético de todas as suas obras. Porto, 1854; Torres, M. J. Vida de José agostinho de Macedo e notícia de seus escritos. Lisboa, 1859; Olavo, Carlos. A vida turbulenta do Padre José Agostinho de Macedo. Lisboa: Guimarães e Ca., s/d.

${ }^{27}$ Macedo, José Agostinho de. Os sebastianistas. Prefação. Sobre o sapateiro Simão Gomes, Macedo refere-se à Vida de Simão Gomes, do jesuíta Manuel da Veiga, publicada em 1625. Sapateiro contemporâneo dos reinados de dom João III, de dom Sebastião e de Bandarra, colega de profissão que se tornaria o "profeta" do sebastianismo, Simão Gomes era conhecido como o Sapateiro Santo e, segundo alguns relatos, chegou a ser chamado ao Conselho de Estado no tempo de dom Sebastiāo, para "dar respostas proféticas" a questôes políticas importantes.

${ }^{28}$ Macedo, José Agostinho de. Op. cit., pp. 17-20.

${ }^{29}$ Idem, pp. 21-22. As Profecias do Pretinho do Japão integram um conjunto incontável de escritos proféticos que circulavam em Portugal, manuscritos e impressos, desde o século XVI, depositados na Biblioteca Nacional de Lisboa, seção de manuscritos, mss.164, n. 11. Profecias a respeito de vários assuntos da história de Portugal feitas por várias pessoas em diferentes épocas. Cópia do século XIX. Em 1821 foi publicado $O$ último desengano dos sebastianistas dado e recebido nas Trovas do Pretinho do Japão. Lisboa: Officina de Antonio Rodrigues Galhardo, Impressor do Conselho de Guerra. O texto de Macedo foi impresso na mesma oficina. Agradeço a Lúcia Maria Bastos Pereira das Neves a gentileza de me ceder uma cópia deste impresso.

${ }^{30}$ Macedo, José Agostinho de. Op. cit., pp. 33- 36.

${ }^{31}$ Idem, p. 38.

32 Antônio Vieira pagaria caro tanto por sua defesa dos cristãos novos, como pela famosa Carta ao Bispo do Japão, escrita em 1659, três anos depois da morte de dom João IV, na qual afirmava ser o Encoberto das Trovas do Bandarra (que para ele tinham valor de profecias) dom João IV ressuscitado, futura cabeça do Quinto Império do Mundo. Para uma análise da vida e do processo sofrido Vieira ver, dentre outros, Azevedo, João Lucio de. História de Antônio Vieira. 3. ed. Lisboa: Clássica Editora, 1992. 2 vols. 
${ }_{33}^{3}$ Macedo, José Agostinho de. Op. cit., p. 40. É importante assinalar que apenas entre os letrados e rei Esperado deixou de ser dom Sebastião. Entre os populares, o Desejado foi sempre o rei desaparecido nas areias do Marrocos. Exemplos dessa permanência podem ser observados tanto entre os quatro falsos dom Sebastião que reivindicaram a identidade do monarca, entre 1584 e 1602, como entre as visionárias que afirmavam manter contato com dom Sebastião em sonho ou em visitas à Ilha Encantada onde o rei e sua família preparavam a volta ao reino. Ver a respeito Hermann, Jacqueline. Op. cit. Capítulo 5: "A volta do Encoberto: entre farsas e encantamentos". Vale citar também Rosa Egipcíaca da Vera Cruz, biografada por Luiz Mott, ex-escrava e prostituta que se tornou beata e visionária e esperava casar com dom Sebastião. Mott, Luiz. Rosa Egipcíaca: uma santa africana no Brasil. Rio de Janeiro: Bertrand Brasil, 1993. Vale citar ainda os movimentos sebastianistas surgidos no Brasil: o da Serra do Rodeador, em Pernambuco, entre 1818-1820, e o do Reino da Pedra, também pernambucano, em 1838, ambos organizados em torno da espera da volta de dom Sebastião.

${ }^{34}$ Macedo, José Agostinho de. Op. cit., p. 45.

${ }^{35}$ Idem, p. 54.

${ }^{36}$ Idem, p. 67. Grifa, no maravilhoso medieval, era um animal fabuloso com cabeça de águia e garras de leão.

${ }^{37}$ Idem, p. 70.

${ }^{38}$ Idem, pp. 71-72.

${ }^{39}$ Idem, p. 74.

${ }^{40}$ Cf. L.M.B. Pereira das Neves. Op. cit., p.199.

${ }^{41}$ Refutação Analytica do Folheto que escreveo o Reverendo Padre José Agostinho de Macedo, e intitulou os Sebastianistas. Pelos redactores do Correio da Pininsula. Prólogo. Lisboa, 1810. p. III-VIII. Agradeço a Lúcia Maria Bastos Pereira das Neves a gentileza de me ceder uma cópia deste impresso.

${ }^{42}$ Idem, p. X.

${ }^{43}$ A recorrêcia, segundo alguns autores, de sapateiros-profetas, teria levado, durante a Época Moderna e em algumas regióes da Europa, a uma identificação quase direta entre os termos. Peter Burke chega a falar em "cultura sapateira". Ver Burke, Peter. A cultura popular na Idade Moderna. São Paulo: Companhia das Letras, 1989. p.64. Essa relação, no entanto, não deve ser tomada sem a análise de cada caso, pois muitos outros ofícios "produziram" profetas nesse período.

${ }^{44}$ Idem, p. 18-19.

${ }^{45}$ Idem, p. 35.

${ }^{46}$ Resposta ás Proposiçôes incluidas no Folheto Intitulado Os sebastianistas por José Agostinho de Macedo, seu author Joaquim Agostinho de Freitas. Lisboa: Officina de Simão Thaddeo Ferreira, 1811, p. ii, iii, 19 e 20, respectivamente.

${ }^{47}$ Idem, p. 18. 
${ }^{48}$ Cartas sobre o verdadeiro espirito do Sebastianismo escrita a hum fidalgo desta Corte por Manoel Joaquim Pereira, Presbytero Secular. Lisboa: Impressão Régia, 1810, p. 11.

${ }^{49}$ Carta de hum guarda-roupa d'elRei D. Sebastião a hum seu amigo nesta Corte, em que, depois de humas breves reflexóes sobre o Folheto intitulado Os sebastianistas Lhe dá huma noticia circunstanciada da Ilha Encuberta, e da existencia daquelle Soberano. Tudo em estilo jocoserio, único proprio de semelhante assumpto. Dada á luz, e vendida aos curiosos por F. P. J. Lisboa: Impressão Régia, 1810, p. 2 e 5.

${ }^{50}$ Macedo, José Agostinho de. Os sebastianistas. Segunda parte por José Agostinho de Macedo. Lisboa: Impressão Régia, 1810, 103 p.

${ }^{51}$ Dentre os quais Sá, José Maria de. Impugnação imparcial do folheto intitulado Os Sebastianistas, por um amador da verdade. Lisboa: Impressão Régia, 1810; Defeza dos sebastianistas, Primeira audiência e despacho que nella obtem composta por Pedro Ignacio Ribeiro Soares. Lisboa: Officina de João Rodrigues Neves, 1810; O Sebastianista Furioso contra o livro intitulado Os sebastianistas por J.M.A. dado á luz Por hum remendão Litterario, que ouviu, e apartou a bulha Sebástica. Lisboa: Impressão Régia, 1810.

${ }^{52}$ Apud Neves, L. M. B. Pereira das. Op. cit, p. 118.

\section{Resumo}

$O$ artigo analisa a sobrevivência do sebastianismo em Portugal no início do século XIX, a partir dos escritos que provocaram a chamada "guerra sebástica", travada paralelamente às guerras contras as tropas de Napoleão Bonaparte.

\section{Abstract}

The article analyses the survival of "sebastianismo" in Portugal on the beginning of the XIX ${ }^{\text {th }}$ Century, based on the writings responsible for the "sebástica war", held in parallel to the wars against Napoleon's troops. 